\title{
C. ORPEN
}

DEPARTMENT OF PSYCHOLOGY

UNIVERSITY OF THE WITWATERSRAND

\section{OPSOMMING}

Die bedryfsielkundige aan die universiteit kom dikwels te staan voor 'n konflik tussen sy rol as "akademiese wetenskaplike" en "professionele tegnikus". Dit word beweer dat hierdie probleem van "tweeledige verbondenheid" tot " $n$ groot mate opgelos kan word as die bedryfsielkundige (en sy studente): (a) dit in gedagte hou dat bedryfsielkunde nie wesentlik 'n onafhanklike dissipline is nie, maar 'n integrale deel van sielkunde-in-diealgemeen vorm, (b) nie sy vak as slegs ' $n$ weerspieëling van die professionele praktyk beskou nie, (c) agting vir sy vak as 'n wetenskaplike dissipline het en nie net as 'n gerieflike werktuig vir bestuur beskou word nie, en (d) die praktyk kan oortuig van die waarde van die vak in 'n verskeidenheid gebiede, wat strek van toetsing tot verbruikersgedrag.

A university lecturer who is also an industrial psychologist is often faced with a problem of dual allegiance. On the one hand, members of the business community often express surprise that an industrial psychologist is a full-time member of a university. On the other hand, many academics are puzzled that a psychology lecturer can spend his time in industrial psychology alone. These points of view bring out the potential conflict for the industrial psychologist in a university setting between his role as an 'academic scientist' and his role as a 'professional technician'. In the first role he is, in a sense, on the side of theory, broad social concern, and the general education of his students; in the second role he is, in a sense, on the side of practical techniques for getting things done, concern with a fairly limited section of society, and the specific vocational training of his students.

The dualism involved in this problem of allegiance is a serious one, but one which is typically more acute at the undergraduate level than at the graduate one. For instance, at the post-graduate level, there is agreement that we are assisting the student in learning the content knowledge, the skills, and the approaches to problems that make for professional competence. However, at the undergraduate level (especially in first courses in industrial psychology), only 
a small proportion of the class are taking the subject for its specific vocational significance. The others are usually taking it merely because of its convenience (for their time-table), or (hopefully) because they hope it will be a broadening and enriching experience in their general education. Faced with these two sets of students, neither of whom are likely to become practicing industrial psychologists, the teacher can easily allow the problem of dual allegiance to interfere with his effective presentation. However, a careful re-examination of the position of industrial psychology, along the lines suggested below, can go a long way toward minimising the difficulties that may be caused by this problem of allegiance.

In the first place, the teacher of industrial psychology needs to remind himself that industrial psychology is, in a significant sense, just the application of the generalizations and findings of 'basic' psychology to behaviour in industrial and business settings. This means that he must always base his teaching firmly on the findings of psychology-in-general. In the second place, the teacher of industrial psychology should not view his role as simply a mirror of professional practice. Already too much professional education consists of telling students how things are done in business and industry. Such an approach is inappropriate to the academic position; academics should be the leaders in their field, not follow behind, although it sometimes seems that industrial psychologists in a few of the larger companies are today ahead of many of their colleagues in the universities. In the third place, the teacher of industrial psychology should consistently resist the temptation to treat his subject as a useful tool rather than a scientific discipline. In this respect, if industrial psychology was merely a set of tools to help managers run their firms more effectively, then it could be taught, like any other technology, for its practical utility to the people who will employ it. In the academic setting the treating of industrial psychology in this fashion is not only incorrect, but also repugnant to the purpose of a university, which is usually conceived as the search for truth and understanding. In order to contribute something positive in the academic setting, the teacher should present industrial psychology as the application of psychological principles and generalizations to behaviour in industry and commerce, with the aim, not only of helping to solve practical problems, but (more importantly) of aiding our understanding of peoples' behaviour in general. In this latter sense, the success or failure of industrial psychology must be measured in terms of the degree to which it contributes to developing repeatable generalizations integrated into some fairly systematic framework about behaviour. If it makes a large contribution in this respect, it will perforce lead to improvements in our understanding and prediction of behaviour. 
By focussing on these three points, the teacher of industrial psychology should not only conquer the problem of dual allegiance, but should, in his teaching, help to identify industrial psychology as an academic discipline with a place among the sciences. In addition, he should have little difficulty in giving industrial psychology a humanistic flavour, by virtue of its concern with people and their legitimate aims in the world of work. Finally, his professional conscience should make him acutely aware of the fact that, since a man's work is one of the most inescapable facets of his life, his subject matter is intimately related to some of the most pressing social issues of our time. If industrial psychology is taught as a scientific discipline devoted to the study of all facets of industrial and commercial life, then these broader social issues will, as a matter of course, be examined and analysed. One of the characteristics of science is that it involves a certain point of view toward the acceptance of new findings and ideas; a willingness to accept the possibility of anything but a reluctance to accept anything as fact until it has been demonstrated. This 'open-minded scepticism' should be conveyed to students taking industrial psychology, by giving them a feeling for the subject (which will remain, long after the content of the course is forgotten), as a fallible, developing, selfcorrecting discipline, that requires the ability to separate established knowledge, which is confirmed by existing facts, from tentative knowledge, which is merely suggested by existing facts. Provided industrial psychology is presented as a scientific discipline this aim should not be too difficult to realize.

Apart from serving an academic purpose, if industrial psychology is presented in this way it should help to produce a group of businessmen (in later years) who see industrial psychology in the correct way: as the scientific study of behaviour as it occurs in industrial and business settings. If they perceive the discipline in this way, they should come to realize that, as far as management is concerned, the significant contribution of the industrial psychologist lies in the fact that he brings with him, not so much a set of rules or specific fact, but rather a method of attacking problems, the socalled scientific method. This means that he relies on empirical observation, rather than subjective opinion, that he collects data as objectively as possible, and that, whenever possible, he carries out experiments to verify the hypotheses he forms from his observations. For instance, his choice of a certain personnel selection test or certain training method is not based on mere commonsense or the recommendations of socalled experts, or on 'hundreds of satisfied clients', but instead on the data he gathers empirically about the actual effectiveness of different tests and different training methods for the particular job and firm. Too often businessmen do not see industrial psychology correctly 
in the above way, but instead adopt either one of two 'extreme' positions. The first 'extreme' position is held by those businessmen who naively attribute 'special powers' to industrial psychologists; the other by those businessmen who regard industrial psychology as merely a fancy way of spelling 'commonsense'. Both these 'extreme' positions are obviously incorrect. With regard to the first position, although industrial psychologists can frequently predict better than untrained persons how individuals are likely to behave in various situations (because of their knowledge of psychological principles), they do not possess any special powers of insight or intuition. With regard to the second position, commonsense views not only lead to contradictory predictions if not put to the empirical test (the task of industrial psychology), but have frequently been shown to be wrong by psychological research. The number of businessmen who hold these 'extreme' views will be considerably reduced if it is appreciated that industrial psychologists are not people who are content to 'please' managers, especially if this can only be achieved by not making the fullest use of available knowledge and techniques, but are people who expect to be judged by their own standards of professional and scientific conduct (rather than the varying standards of different business firms).

Despite ignorance about industrial psychology on the part of many South African businessmen, the level of acceptance of industrial psychology in South Africa seems to be at about the same level as in the United States and considerably higher than that in Britain and the rest of Western Europe. For instance, a recent survey by the author of a fairly representative sample of South African executives found that $64 \%$ of them were willing to engage an industrial psychologist - this is slightly higher than the figure of $62 \%$ reported in United States studies and much higher than the figure suggested by studies done in Britain and the rest of Western Europe. The relatively high level of acceptance of industrial psychology in South Africa, despite the fact that we are supposed to 'lag behind' the more developed countries of North America and Western Europe in other respects, is probably due to the combination of a number of factors. In the first place, the proportion of registered psychologists in the country who regard themselves as industrial psychologists (30\%) is much higher than the proportion of registered psychologists in the United States; Britain and the rest of Western Europe who regard themselves as industrial psychologists ( $8 \%)$. In the second place, despite the country's small white population, it has an internationallyrecognized research and training centre for industrial psychology in Johannesburg - the National Institute for Personnel Research (N.I.P.R.). In the third place, relatively more time and effort is devoted to industrial psychology, especially at the undergraduate level, at South 
African universities than at American, British and European universities. For instance, in South Africa, unlike other countries, courses in industrial psychology are offered as part of the undergraduate programme in every Department of Psychology of the major universities.

Moreover, a number of universities in South Africa, e.g. Stellenbosch, Orange Free State, Potchefstroom, Port Elizabeth, the University of South Africa, Fort Hare and DurbanWestville have separate Departments of Industrial Psychology. Although the industrial psychologists attached to the various universities are mainly concerned with teaching and their own research, many of them do consulting work on an informal basis for businessmen who approach them. There are also industrial psychologists attached to most of the graduate business schools at South African universities, who engage in consulting work as well as teaching. In the fourth place, in addition to the NIPR, research in industrial psychology, especially in the areas of test construction and validation and of manpower utilization, is being undertaken by the Human Sciences Research Council (HSRC), working within the Department of National Education (former the Department of Education, Arts, and Science). Although this institute is more concerned with broad social and educational problems and the co-ordination of research undertaken in various universities and institutes, a lot of their work has fairly direct implications for industrial psychology. Finally, despite its relatively small white population, South Africa has two well-organized national organizations of psychologists, both of which provide for the registration of industrial psychologists. They are the South African Psychological Association (SAPA), which is affiliated with the International Union of Psychological Sciences, and the Psychological Institute of the Republic of South Africa (PIRSA).

In the study mentioned earlier it was the younger, better-educated, executives in the larger firms who were more favourably disposed towards industrial psychology, and more inclined to employ an industrial psychologist. Since very few of these executives had taken any courses in the subject this is an encouraging figure. If we make the reasonable assumptions that the younger executives set the 'tone' for the future, that the general level of education of South African executives continues to rise, and that the present trend towards larger firms continues, then the fact that youth, education, and firm size were all found to be positively related to the acceptance of industrial psychology is another hopeful sign that the discipline will be accepted even more by the South African business world in the future than at present. As indicated in the present paper, this trend should be accelerated and the purposes of higher education should be well-served if teachers of industrial psychology have a broad 
conception of their subject as an important scientific field of inquiry into broadly human problems of work.

\section{SUMMARY}

The university industrial psychologist is often faced with a conflict between his roles as an 'academic scientist' and as a 'professional technician'. It is argued that this problem of 'dual allegiance' can be resolved to a large extent if the industrial psychologist: (i) reminds himself (and his students) that industrial psychology is not a special discipline on its own, but is an integral part of psychology-in-general, (ii) does not view his subject as just a mirror of professional practice, (iii) has regard for his subject as a scientific discipline, and not just as a useful tool for management, and (iv) convinces practitioners of the value of the subject in a variety of areas, ranging from testing to consumer behaviour. 